\title{
THE “TROJAN HORSE" PLOT AND THE FEAR OF MUSLIM POWER IN BRITISH STATE SCHOOLS
}

\author{
Tahir Abbas*
}

\begin{abstract}
In 2014, an alleged "Trojan Horse" plot to Islamise education in a number of schools attended predominantly by diverse Muslim pupils in the inner-city wards of Birmingham raised considerable questions. Ofsted investigations of 21 schools explored these concerns at the behest of the then Secretary of State for Education, Michael Gove MP. At the head of this so-called plot, a certain Tahir Alam, once a darling of New Labour's policies on British Muslim schools, faced the brunt of the media and political furore. Based on a series of face-to-face interviews with Alam in 2015 and 2016, this paper provides a detailed insight into the allegations, the context in which they emerged, and the implications raised for young Muslims in the education system. Ultimately, as part of the government's counter-terrorism policy the accusations of the "Islamisation" of education in these "Trojan Horse" schools foreshadowed the additional securitisation of all sectors of education. However, there was neither the evidence nor the legal justification to ratchet up anti-extremism education measures that eventually followed; namely the CounterTerrorism and Security Act 2015. The consequences of the negative attention heightened existing Islamophobia but, paradoxically, they also limited the opportunities for de-radicalisation through education.
\end{abstract}

\section{INTRODUCTION}

In the summer of 2014, the then Secretary of State for Education, Michael Gove MP, prompted an investigation into a 'plot' to "Islamise" the local education of predominantly Muslim pupils in a number of state schools in the inner cities of Birmingham. Considerable fear and alarm in media and political circles emerged over this apparent crisis. The emphasis on the "Islamisation" of state schooling directly supported the dominant Islamophobic rhetoric among political and media actors quick to demonise conservative Islam. Such neo conservative sentiments operated within a framework that desired to shape political identities

* Assoc. Prof. Tahir Abbas Ph.D. F.R.S.A. (University of Leiden). 


\section{THE “TROJAN HORSE” PLOT AND THE FEAR OF MUSLIM POWER IN BRITISH STATE SCHOOLS}

through a narrow spectrum of supposed British values. Both cultural and political notions were instrumentalised in this framework, with the defining parameters presented in exclusivist terms, which were: (a) those who did not espouse certain (cultural) values were somehow upholding extremist views and were (b) a threat to democracy (political values) and, as such, to the status quo (Robinson 2015).

This paper explores the impact of this recent social and political episode on British Muslims who already experience considerable Islamophobia (Allen 2010). The emphasis here is on the realm of education, and the ways in which the state presumed to act in response to protecting vulnerable children. Implications for educational leadership and the securitisation agenda also emerged. Based on a series of interviews with Tahir Alam, the supposed "ring-leader" of this "plot", this paper addresses the following concerns.

First, the dominant discourses that led to the charge of

- "Islamisation" in Birmingham schools.

- the nature of the accusations that were initially raised, including aspects of the various investigation reports.

- educational leadership and the counter-radicalisation agenda.

- how the "Trojan Horse" saga exposed the various fears of Muslim self-empowerment.

In conclusion, the "Trojan Horse" tale in Birmingham schools uncovered deeply entrenched anti-Muslim sentiments in British politics combined with ongoing patterns of racialisation and victimisation of British Muslim groups.

It also demonstrated further disregard of the actual lived experiences of communities and the social, cultural, economic and political realities they face (Ahmad and Sardar 2010). The government not only fell into the spell of antiMuslim policy dogma but it also fuelled further mistrust between communities. There was some mismanagement afflicting certain schools, but the investigations failed to establish that there was any "plot" to "Islamise" schools or their mainly Muslim pupils. In an atmosphere of acute Islamophobia and political interference, the uncomfortable reality is that the victims of this episode were young Muslims who continue to face considerable barriers to success and social mobility because of limitations in the education system (Hoque 2015) and wider anxieties of structural and cultural racism. Leadership, often presented as a defining topic, was denied to those wanting to be Muslim and British, interconnected with the removal of opportunities for individual and group empowerment of a body of already beleaguered people whose futures remain precarious in a neoliberal, post-Brexit vote, environment (Shah 2015). 


\section{THE POLITICAL CONTEXT}

In 2014, in the fourth year of the coalition government of the Conservatives and Liberal Democrats, the then Secretary of State for Education, Michael Gove, motivated by neoconservative ideology, aimed to identify and weed out the alleged "Islamisation" of state schools. For Gove, the substance of this alleged plot ranged from managing senior appointments, to revising teaching practices and enforcing certain Islamic principles in the classroom, namely gender segregation and limiting the teaching of evolution. It was also argued that "extremist preachers" were invited to speak to pupils in schools at the expense of taxpayers. Andrew Gilligan, hailed for exposing the "dodgy dossier" used by New Labour in 2003 to make a case for the war on Iraq, turned his attention to British Muslims. In 2014 and 2015, Gilligan wrote a series of damning articles in The Telegraph that catalogued the extent of the "Trojan Horse Plot", naming individuals and their interlinkages, including printing mobile phone text communications between significant actors (Gilligan 2014).

In his extensive scripting, Gilligan censured "Muslim apologists" for being in denial about the extent of Islamism in these schools. However, there was no precise evidence on the specifics of any so-called plot nor how it may have arisen in the light of numerous checks and balances at the local authority and central government levels. Only after the revelation of the now infamous "Trojan Horse letter", whose provenance remained inconclusive, Gove appointed Peter Clarke. A counterterrorism officiator, formerly of Scotland Yard, Clarke's role was to explore whether there were any specific counter-terrorism implications raised by these schools Pidd and Dodd 2014). Gove believed that the Islamist threat was severe and deep, and that this "Trojan Horse Plot" was real and urgent to the extent that the Department of Education (DfE) ought to have a major role in thwarting it. For Gove, an emphasis on "British values", tantamount to "integration" in his eyes, was regarded as the principal concern, even though both terms are ambiguous at the best of times. In his prepared statement to Parliament, Gove reeled out a long list of so-called extremist instances in six Birmingham schools allegedly most affected by the so-called plot. However, he demonstrated acute difficulty with concepts such as "mujahedin" and "jihad". He also took "non-violent extremism" as being equal to "religious conservatism"- conflating these notions as suggestions of extremism per se.

The Peter Clarke publication (2014) stated that there was no "evidence of terrorism, radicalisation, or violent extremism" in the schools that were under investigation. However, he articulated that, “... there are a number of people, associated with each other and in positions of influence in schools and on governing bodies, who espouse, endorse, or fail to challenge extremist views". This 


\section{THE “TROJAN HORSE” PLOT AND THE FEAR OF MUSLIM POWER IN BRITISH STATE SCHOOLS}

conspiratorial language was damaging enough. The Clarke investigation preceded a Birmingham City Council report, led by Ian Kershaw, an ex-headteacher (2014). Both reports resulted in the schools coming under the direct authority of the Education Secretary, with Ofsted subsequently granted powers to carry out their inspections separate from the DfE. In total, Ofsted inspected 21 schools in Birmingham, eventually submitting their report to the Education Funding Agency. All of these enquiries led to immense discussion and debate over their relative merits and the implications they raised for the schooling of British Muslim children. The reality was less about Islam in schools. It was more the concern of empowering parents, governors and local teaching staff, which is permitted under the mandate of the academies system, one that Gove encouraged from the outset. However, Gove's personal identity politics and political aspirations had their imprints all over this matter (Hasan 2014). These actions also affirmed existing narratives around the securitisation of multiculturalism, where the idea of faith was projected as a "moral panic" by various media and political discourses, reversing New Labour government policy that regarded faith as a catalyst for social cohesion. During this period, the policy moved "between 'soft community cohesion', in the form of pedagogical interventions, to 'hard community cohesion', in the form of coercive forms of surveillance, with alarming speed" Cowden and Singh 2014). Ultimately, "the Trojan Horse forgery in Birmingham not only reflected Islamophobic tropes, fantasies and simplicities which already existed but also acted as a gift horse for certain pre-existing agendas and interests" Richardson (2015).

Although there was no evidence of extremism in the 21 schools investigated, 5 schools were placed under special measures. Although the Ofsted reports highlighted management gaps, they also emphasized local knowledge and enhanced community engagement among staff as adding to the education of young children, all of which was ignored by the media and the political debate at the time (Mogra 2015). The Park View Trust held three of the schools under its umbrella. When the Trust realised their schools would be under special measures, their public statement revealed the extent of loss and betrayal sensed by many (Morris and Wintour 2014). It evoked the sadness they felt for young people endeavouring to obtain an education in some of the poorest areas of Birmingham. It offered sympathy to dedicated professionals who strived to break the link between "disadvantage, demographics and destination" in education. The government took a particularly hard-line on these schools because of existing fears around "Islamisation" in society, whether in the form of "sharia councils", the evergrowing demographic profile of visible Muslim communities in urban areas, and the concerns emanating from worries over violence and terrorism. In the post-9/11 climate, Islamophobia is exacerbated at times of terrorist incidences, which then feeds the rhetoric of the radicalisers. 
No instances of extremism emerged in the schools, but the concentration on "ideology" was the dominant narrative. Here, there was a remarkable consistency among three investigative processes James 2015). However, the lack of clarity on what this ideology was supposed to be suggested more than just ambiguity. Rather, there was a premeditated conception that an undefined ideology spawned certain practices, including "massaging" appointments and the use of an "Islamised" curriculum. Linking them all was a common concern, conservative Islamism. The Ofsted reports alluded to teachers being "bullied" by governors and that the local authority had not properly scrutinised practices within these schools. This "non-violent extremism", as it would be later put, referred to religious practices such as collective worship or taking pupils to trips to Islamic holy sites in the Middle East, all within the law. Schools with over 95\% Muslim populations have a right under the legislation to teach Arabic as an additional language, and to introduce voluntary religious worship. Most of the "Trojan Horse schools" had sought the necessary determination from the local authority, but in some instances they had not been reissued. The "plot" became the precursor to a range of widesweeping changes that went ahead, including random spot-checks from Ofsted or the promotion of "British values" in the national curriculum.

\section{INSIDE THE “TROJAN HORSE” AFFAIR}

This paper utilises data from an in-depth semi-structured interview process with Tahir Alam during three separate occasions in 2015 and 2016. I initially reached out to Alam in 2015, approximately six months from him resigning as chair of Park View schools, and after the DfE prohibition order preventing him from acting as a governor or working in any capacity in the education sector. Two of these interviews were in his home in Birmingham in 2015 and one in Istanbul in 2016. Interview questions conncetrated on the "Trojan Horse" "scandal", but they also focused on aspects of his perspectives on wider concerns relating to British Muslim education. The responses generated during these interactions formed a grounded theory approach based on an insider perspective on British Muslims in education with a specific spotlight on the "Trojan Horse" matter. I also had access to private correspondence between Alam and the investigators of the schools in the so-called plot. Objectivity was essential, particularly when both the researcher and the researched are of similar ethnicity, age, religious identity and neighbourhood backgrounds. Reflexivity ensured that the analysis was impartial and analytical, adhering to ethical and methodological guidelines in social science research to the fullest (Abbas 2010).

Tahir Alam was born in 1968 in Dadyal, in the district of Mirpur in Azad Kashmir. He came to Birmingham at the age of 10, and attended Nansen Primary 


\section{THE “TROJAN HORSE” PLOT AND THE FEAR OF MUSLIM POWER IN BRITISH STATE SCHOOLS}

School and later Park View Secondary School, two of the three schools that were under the Park View Trust. During the late 1990s, I met with him on two occasions when I was working on my research on the education of Birmingham South Asians. The research I carried out identified teacher (mis)labelling, setting and streaming, and concerns relating to prejudice and stereotyping that restricted young Muslim children in schools (Abbas 2004). In exploring both successful selective schools and their inner city state school counterparts, the analysis that explained differences in outcomes fixated on social and cultural capital. Classed families had greater means of support for their children. By "playing the game" of selection they ensured their children entered stronger schools, leading to successful educational outcomes at one extreme. Families whose experience was inner city deprivation, unemployment and disadvantage were not able to take advantage of the more effective schools found in the outer areas due to restrictions to intake as well as the barriers to entry created by income or entrance tests. Ultimately, their locations meant that children were concentrated in predominantly weak or failing schools in disadvantaged areas, reproducing patterns of social immobility and inner city entrenchment, generation upon generation.

The prevailing post-war paradigm on education and social class has a priori identified the direct association between these two concepts to such an extent that they are inseparable in the minds of many Halsey, Heath and Ridge 1980). That is, education leads to class mobility, class mobility is achieved through education. Thus, in extending this argument, minority children underperform in education due to their ethnic and class characteristics. However, research has also identified that stronger schools can raise the average performance levels of pupils from weaker backgrounds, while weaker schools reduce the average performance of pupils from more classed backgrounds. The idea of the school effect (Smith and Tomlinson 1989) suggests that the school makes all the difference, and the view taken forward is that if there is improvement in weak schools, from the point of management, leadership and organisation, and a curriculum that enhances the pupil-teacher-school interaction, dramatic changes in outcome can be determined.

In the 1990s, the move to the New Right in education, supported under the New Labour government, furthered the process of marketisation in education. It provided parents and children with greater choice and therefore (supposed) greater opportunity (Tomlinson 2008). As a campaigner and activist in education, Alam became the Education Spokesman for the Muslim Council of Britain in 2003, a national Muslim umbrella organisation with considerable influence at the time. His aims were to ensure that British Muslim children were able to take advantage of this new regime, ensuring they too could benefit from the liberalisation of education. The role of school governors in steering the management and leadership of schools meant that parents and community members could play a greater part 
in the running of the schools. The process also ensured that too much power did not rest in the hands of head-teachers or local authority policy makers whose perspectives might have become outmoded in the light of new challenges facing schools. These changes met the needs and demands of a more competitive education system that allowed for greater independence at the school level.

In September 2015, I interviewed Alam at his home, and over the next few months, further interviews and email exchanges permitted the completion of the data gathering process in Istanbul in early 2016. The following is the essence of this extended 18-month long conversation.

\section{OPPORTUNITY OR DESIGN?}

Since his role with the MCB, Alam gradually gained momentum with his work with like-minded others in his local area to help turn around the dramatic underperformance of young Muslim children in the inner city areas of Birmingham. He diligently followed the guidelines and rules set out by Ofsted, allowing parent governors to have a critical role in appointing head-teachers. I asked him if he saw this as an opportunity.

I did not accept the idea that these children were destined to fail and that there was no alternative to their predicament. I saw the consequences of educational failure first hand in the local community: unemployment, crime and disillusioned youngsters ... In Park View School, for example, when I become a governor in 1997, the results were just 4\% (5+ GCSE A-C). This was a school that I went to myself as a pupil and I decided to get involved.

In elaborating further on the question of how he directed his interests towards becoming actively involved in shaping the educational processes, he said,

The participation from parents in school life from the local community was almost negligible. The vast majority of parents did not feel they had the confidence to be involved in an active manner at the decision-making layer of the school. In trying to address this chasm, I tried to encourage people to be involved in schools by attending parent's evenings for their children, supporting their children at home and by trying to become a parent governor if they have the time and were waiting to have a go at it. I opened tuition classes also.

I wanted to get a sense of how he believed his role as a governor had made a difference and how he managed to maintain a fine balance between ensuing fairness and equality regarding appointments and policy without it descending 


\section{THE “TROJAN HORSE” PLOT AND THE FEAR OF MUSLIM POWER IN BRITISH STATE SCHOOLS}

into nepotism, as this was a specific accusation levelled against the "Trojan Horse" schools. He articulated,

Let me say it from the outset that any suggestion that we were engaged in some kind of nepotism or favouritism is rejected ... We encountered a lot of resistance to change that was needed to transform the schools into successful schools. A culture of excuses had to be overcome ... This took a longer time to accomplish, as a common vision needed to be established between all the stakeholders, which were focused on the most important stakeholder, the children in the school.

In many senses, Alam became involved in the education system because of a burning desire to see that his co-Muslim community did not persistently suffer as a result of schools that continued to fail the young Muslims predominantly concentrated in the local area and, hence, in the local schools. He was committed to challenging a culture of acceptance that deemed it perfectly viable to regard underperformance as a function of the ethnic and cultural characteristics of the community and the schoolchildren, not the running of the schools. Moreover, it was carried out through understanding and applying the system, and not by resorting to favouritism or any other form of cronyism.

\section{Challenging the Gaze on Muslims and Differences}

After the events of 9/11 in the United States and various acts of terrorism carried out by Muslims in Britain and Europe during the 2000s and more recently, the negative attention on Muslims as "suspect communities" has grown severely (Mythen, Walklate and Khan 2009). I asked Alam if these were additional concerns that motivated his work as Chair of the Park View Trust and what precisely he hoped to achieve by doing so. Alam emphasised:

We wanted the school to be inclusive of all the communities the school served and to value the cultural background of all the children in the school. I believe that confident children achieve well, so developing the confidence of children is critical to their educational success in education and in wider society ... Children must feel comfortable in their own skin ...

Egalitarianism is an important starting point for Alam. Undoing the disadvantage that Muslims were increasingly facing in a hostile anti-Muslim atmosphere further motivated him in his efforts to reduce the achievement gap, partly enhanced by the institutional practices within the education system. He further added: 
Discrimination and Islamophobia were very palpable in many people's attitudes and behaviour... I remember distinctly, following the events of 9/11, I personally conducted assemblies within the school to emphasise that from an Islamic point of view this was completely wrong and immoral to kill innocent people, regardless of the wider political context. For Muslim children Islam is naturally a reference point for who they are and where they draw their values from primarily. We had to take account of this and work with it-not to ignore it and pretend otherwise.

Hegemonic narratives produced by neoliberal elites in media and politics regard Muslims as possessing certain cultural attributes that go against the grain of British society. Before the "Trojan Horse" narrative erupted, I asked how the Trust schools were addressing these concerns. He elaborated:

We did not see the cultural background of children as being problematic or something that needed to be rectified or improved upon. Nor did I see the cultural issues as being irreconcilable or unbridgeable ... We deliberately and con sciously adopted an attitude and policy of being inclusive of the communities that we served. Examples [include] providing washing facilities, prayer facilities, conducting Islamic service for children in the morning, making special arrangements for children that are fasting during Ramadan, and within the curriculum introducing community languages, for example Urdu and Arabic alongside Spanish and French. Children should feel and be an integral part of British society ... No one should have to choose between being Muslim, Jewish, Christian and British. They're not opposites and certainly not irreconcilable.

The post-9/11 "war on terror" climate undoubtedly changed the perception landscape concerning Muslims. It has added to existing fears and enhanced others relating to extremism and terrorism (Kundani 2004). For Muslims using legitimate existing policy measures to reorganise themselves in response to the ever-growing challenges they face, the levels of suspicion do not abate. This is because while there is a sense that Muslims are a threat to society due to certain innate characteristics, Muslims who defy the dominant templates do not become "a success story" in their own right. Rather, they can encounter even greater trepidation and hostility from dominant society. Unless, that is, they seemingly lose their "conservative Muslimness" in the pursuit of integration, or through attempts to liberalise or reform Islam itself. Advancing the idea of being both British and Muslim by being "less Muslim" is a requirement of the neoconservative paradigm. 


\section{THE ACCUSED}

The so-called "Trojan Horse letter", first made known in March 2014, was the start of the events that led to the furore of "Islamisation" in Birmingham schools, eventually leading to the actions ordered by Michael Gove as Secretary of State for Education at the time.

The foundations of the accusations rest entirely on the content of this now infamous letter, whose provenance remains officially unbeknown, but with consequences acutely felt by the communities concentrated in the schools that were ultimately taken over by the centre. I asked Alam if he had any idea about where this letter originated and who would make such claims. He responded:

I am firmly of the opinion that the letter was written by a headteacher who wrongfully believed that I was behind, or at least supporting, certain actions that affected her position in the school. The motivation for the letter were twofold: one, the invention of the Trojan hoax plot would provide an explanation for the predicament of the headteacher but also then depict her as victim and target of this plot. Secondly, it served the purpose of seeking revenge for something that I was supposed have had done. It is as simple as that, as astonishing as it may sound.

After some hesitation on the part of the local authority, the government accepted the letter as prima facie evidence of radicalisation in schools, however there was no attempt to identify its source. Rather, for Alam, the political climate at the time was the driving force. He had his suspicions regarding the letter but these were never taken into consider ation. He added further added:

The Department for Education or Birmingham City Council have never been interested in trying to identify who authored the letter and or to try to establish its authenticity. For example, Peter Clarke in his report categorically says that he is not interested in who wrote the letter or its authenticity, he was simply interested if there was any truth in what was being claimed in the letter. The people involved are known to me and are of Muslim faith background. I believe the letter was planned and framed in such a way to see to seek a political intervention in her own case and to make our schools a target by a neocon Secretary of State whose antipathy to Islam and Muslims is not a secret, if his book "Celsius 7/7" is anything to go by.

Once Parliament made the case for an investigation, I asked Alam why he thought Michael Gove appointed Peter Clarke, whose forte is counter-terrorism. 
Had the government already made up its mind about what was allegedly going on in the schools? Was Clarke there to affirm some pre-existing concept, legitimising a policy on "values", which conflates radical violent Islamism with conservative trends among Muslims? He responded:

Triggered by the Trojan hoax letter, [the process] was, as I described at the time, a witchhunt from A-Z. We were under attack by media, the Department for Education and Ofsted and this was a coordinated effort. In a witchhunt, evidence is not important. What is important is that somebody is hanged and that a point is made. Inspectors and investigators were coming in to look for extremists, radicals and terrorists. Of course, they didn't find any, but they did some "conservative practices" and "conservative" Muslims- this was enough. The appointment of Peter Clarke, whose experience is in counterterrorism, speaks volumes about the intention and the motivation for these investigations.

Charging a senior counter-terrorism officer with the task of investigating the issues, someone with little or no understanding of education, was a deliberate choice. It prematurely directed wider perceptions on the topic, potentially prejudicing the findings. Given the media and political attention on the topic, there was also the possibility that anything neutrally stated would remain invisible in the minds of the many. Alam was particularly agitated by the entire process, suggesting that it reflected patterns of vilification, stigmatisation and, ultimately, racism. He added:

Peter Clarke knows nothing about education. This is very apparent from his report. Quite frankly, his report is not worth the paper it is written on because the allegations that he documented in the main were never corroborated or verified or cross checked with those who were accused. His report predominantly relies upon hearsay and people making claims that certain things happened or certain things were said ... His report is a work of fiction because it gives a fictional account of the school and its activities and he gives a fictional account of the people who were running the schools. The interventions in our schools were wasteful and racist and they serve the purpose of discrimination and lowering the academic success of the schools.

\section{"I WALK A LONELY STREET"}

As the accusations regarding the "Trojan Horse plot" unfolded, with incessant negative media and political attention demonising the alleged protagonists, and as 


\section{THE “TROJAN HORSE” PLOT AND THE FEAR OF MUSLIM POWER IN BRITISH STATE SCHOOLS}

the investigation reports came out in July 2014, Alam faced ever-greater pressure. Paparazzi were now outside his home. His every movement was under intense scrutiny, and he felt he was under "house arrest". In an instant, his life turned upside down. Moreover, these same media and political systems were simply not interested in his rebuttals. Rather, the dominant actors in this play had already made up their minds. In September 2015, the DfE banned him from working, taking part or becoming involved in the education of young people. Since the mid-1990s, he had been fully committed to education, and, as the performance levels demonstrated, it would appear that he achieved considerable success in the process. I asked him what this entire episode made him come to understand about the Muslim experience in Britain, and how the experience affected him personally. He was pensive at first but then opened up to present his carefully developed thoughts. He said:

I think the Muslim experience as a migrant community, settling in this country, has not been any different from other communities that preceded us. For example, the Jewish community, people of Irish background and black backgrounds have faced challenges prejudice, discrimination and racism. Once we take away the hype around Trojan hoax, what we are left with, quite simply, is blatant discrimination against Muslim children, Muslim parents, Muslim teachers and Muslim governors, who it is believed cannot be, through democratic channels, trusted to influence, shape or run the education of their own children - a principle enshrined for others. In other words, they need to be saved or "liberated" from such influences, which are deemed to be inhibiting integration.

He went on to add that identity is an important matter in education but for too long the education system has ignored Muslim schoolchildren (Jenkins 2002). But as the law has changed to take into consideration Muslim educational needs and demands, the wider political and cultural forces have become critical of "Muslimness", equating it with failed multiculturalism and, in current periods, terrorism and extremism. However, for Alam, this is an opportunity for changethe chance to improve social relations at a time of intense pressure on British Muslims, and that the education system should actively take up the challenge. $\mathrm{He}$ added:

Within the educational context, I am firmly of the view that children should not be expected to leave their backgrounds in terms of their faith or culture outside the school door. Rather, the school should be an inclusive place where children of all backgrounds can feel that this is their school and be able to 
express themselves and have their religious needs met to the extent possible. There is no alternative to multiculturalism except discrimination, oppression and fascism. What monoculture can everyone subscribe to?

I asked him where he goes from here. What are the implications for British Muslims in education? In addition, what lessons can we all learn from this entire saga? He was saguine but remained sorrowful that a great opportunity, and years of progress and learning that led to the positive changes introduced, were lost. $\mathrm{He}$ said,

The mistrustful intimidatory and bullying culture that has resulted within schools following the Trojan hoax affair has become a generational struggle for the Muslim community, which must be overcome. It may even take a civil rights movement to restore parity and equality for Muslim communities in Britain. There is a long road ahead, which is going to be bumpy, no doubt, but we must not succumb to the sinister aims of those who seek to marginalise and frighten the Muslims into adopting the "mute" mode or "parked-up" mode.

Naturally, he was aggrieved but expressed greatest concern for the many young Muslims who would suffer the consequences of government actions for the rest of their lives. His aims in devoting his professional working life to education were to reverse the existing trends of underperformance through limited leadership, management and delivery. The "Trojan Horse" affair undermined his life's work, devaluing the learning that has ensued, but also returning to the dominant paradigm of demonisation and denigration. He added,

It is a matter of great sadness for me and for all those who were involved in the school that all our good work has now been brought to an end and the schools that we created are now underachieving and will probably continue to undera chieve over the decades to come. Parental voices are being ignored and the involvement from those whose children come to the school has been almost entirely eliminated. The political intervention in our schools has resulted in the legitimisation, legalisation and institutionalisation of discrimination against Muslim children and made Islamophobia acceptable.

He remains committed to education in spite of all that has happened, and all that continues to prevent him from the work he is passionate about. He is fighting to have the ban against him lifted and to one day work again with young Muslim children to transform them, through education, into an engaged, participatory and active citizenry. 


\section{TROJAN HORSE SCHOOLS-VICTIMS OF THEIR OWN SUCCESS}

In many ways, the question of educational leadership is a significant matter to emerge from this saga. The directives introduced by Ofsted allowing schools greater autonomy feed into the neoliberal agenda manifest in education policy, a continuation of school policies that surfaced at the start of the 1990s. It has been a way of introducing market forces into education. However, in such a set of circumstances, there is a tendency for the free market to enhance existing divisions between stronger and weaker schools. But it is also possible to introduce innovative educational methods to encourage and motivate children in schools as well as to improve their performance in examinations. In this space, the "Trojan Horse" schools became a victim of their own success. These schools took the opportunity to use the system to change seemingly intractable patterns regarding performance. By doing so, they evoked the twin concerns of radicalisation and extremism at a time when these concepts carry considerable weight but also great misunderstanding.

Thus, leadership among Muslims in education has become the defining area of discussion. There is a genuine case made for recognising the interactions between teacher and learner as much as the process of education itself (Shah 2006). The situation is further problematised due to the hindrances to career progression experienced by some Muslim teachers in certain minority contexts (Shah and Shaikh 2010) and among young Muslims in education struggling to reconcile their faith-based identities with their national, ethnic or cultural allegiances (Bhatti 2011) especially men. In 1997, New Labour proceeded to fund Muslim schools in the face of a diverse society and government rhetoric towards multiculturalism. But for migrant, diasporic and transnational communities, being a Muslim minority remains a charged and contested field. It is also loaded with complexities beyond the simple dividing rhetoric of Muslim or non-Muslim (Salih 2004). There is some indication that British Muslims in education wish to move to a position that emphasises coherence and interdependency between Muslimness and Britishness ( Meer 2009) but it would be far too simplistic to essentialise Muslims into a single category as myriad differences exist between and within groups in Britain (Tinker and Smart 2012). There are also differences between and within generations (Kashyap and Lewis 2012), and elsewhere in Muslim diasporas across the Western and Eastern worlds (Daun and Walford 2004). All the same, there remains an opportunity to positively mobilise "Muslimness" as a bottom-up political identity that contests the dominant negative paradigms, in the process expanding the reach of the concept of "Muslim" among both empowered as well as marginalised groups (Adamson 2011). The "Trojan Horse Schools" demonstrated 
how it could be possible, but their efforts were thwarted by a charged political context driven partly by Islamophobia and neoliberalism in Western Europe.

\section{NO SCHOOL IS VALUE FREE}

As a result of this "Trojan Horse" "plot", there is further risk that educational autonomy is now perennially jeopardised because of attempts by government to expeditiously seek to identify vulnerable children or those at risk of "radicalisation". There are numerous considerations here, not least the well-being of young children, but there is also pathologisation. Educational freedom is sacrosanct in the realm of democracies. Shutting down critical voices or labelling them as radical requiring counter-terrorism or de-radicalisation "treatment" is tantamount to indoctrination (O'Donnell 2011). The state uses the education system to change the way young people see the world, not in a fair or balanced manner, but in a climate where there is both fear and hate that demonstrably surrounds young British Muslims today. The essence of the anxiety is that British Muslims are opposed to British freedoms and liberties, thereby legitimising the additional scrutiny directed towards them. However, no school is value freeand neither is secularism or liberalism. Moreover, as other academies and free schools have demonstrated mismanagement, none carries the "extremist" categorisation. In reality, the entire "Trojan Horse" affair exposes more about dominant political and cultural discourse in education, where perceptions blur to the extent that all conservative Muslims are projected as a risk. The "Trojan Horse" investigations were slapdash, presumptuous, weak, and in many cases simply wrong. The impact that it has had on Muslim communities in the inner-city areas, however, will have much longer effect, including furthering Islamophobia and anti-Muslim racism (Awan 2014).

Sensational newspaper headlines such as "Trojan Horse Jihadist Plot"35 to take over Birmingham schools served only to conflate British Muslims with terrorism, spreading divisions and adding to fear on all sides. However, in reality the "Trojan Horse" schools reversed dominant thinking on schools supposedly failing because of the pupils who make up their intake. For decades, the prevailing argument was that these schools underperformed because their pupils were of lower ability or from lower socio-economic backgrounds, preventing young people from accessing the social and cultural capital necessary to perform comparably to their middle-class counterparts. Before the "scandal", the same pupils from the same backgrounds, but now in schools with freedom and power to be run independently while maintaining the national curriculum as state schools, improved their performance fourfold. It represented a significant departure from the mainstream view that social class is the main determinant of educational 


\section{THE “TROJAN HORSE” PLOT AND THE FEAR OF MUSLIM POWER IN BRITISH STATE SCHOOLS}

outcome. Crucially, it was a case of Muslim professionals and parents taking matters into their own hands, and subsequently succeeding against conventional thinking. It was a triumph in the face of adversity, but it challenged the status quo and revealed the fallacy of the ascendant narrative on ethnic minorities in education in the post-war period. In the end, there was little evidence that these schools abused the system or were mismanaged. Rather, it was the opposite. They took "underclass", working class and poor young people and instilled into them a sense of achievement and confidence comparable to their middle class counterparts and succeeded when they had been written off for decades.

\section{THE ROLE OF TEACHERS}

The assumptions of thinkers and observers wedded to the idea that social class, "neighbourhood effects" or the fact of diversity itself are the reasons for the underperformance of minority and/or poorer children in education are under severe test. Indeed, poor schools create poor neighbourhoods-not because poor schools are a function of children from poorer backgrounds. The role of teachers is also crucial to success. Motivating, inspiring and dedicated professional teachers can and do make all the difference. Teachers can revolutionise the lives of children with greater leadership, management and vision. The reality is that these "Trojan Horse" schools forever changed the lives of young people because they transformed schools. The "Trojan Horse" saga, as a case study of Muslim minority experiences of ethnic and religious identities in Britain, and in the context of educational resources, curricula, pedagogy and local problems, appears to validate the perspective that the nature of social relations and the perceptions of the "other" held by the dominant "other" remain crucial sources of anxiety.

Insights based on social research provide a standpoint on educational process, including dynamics relating to home-school links, curriculum content and the values placed on inherent differences among diverse groups, but there remain many additional problems facing young South Asian Muslims in English schools today. After 70 years of post-war immigration, settlement and adaptation, many of these communities continue to face racism, prejudice, intolerance, bigotry and discrimination. It affects educational outcomes and identity politics, where dominant notions of race and nation thrust Muslims into the limelight as the most racialised, objectified and "othered" groups in education (Shain 2013). Given the changing dynamics of an increasingly visible Muslim and South Asian minority in various British towns and cities, the view is that communities must integrate to succeed. However, adaptation to and incorporation into society has simply not happened due to discrimination and exclusion. This is not to argue that social and 
cultural integration is the route to success, but rather to assert that prevailing external factors are forcing communities apart not together.

\section{VALUES AND PUBLIC POLICY}

The "Trojan Horse" affair demonstrated that the schooling of young Muslims will remain under fire for some time. All the while, Muslim communities will suffer the most in inner city areas-habitually neglected, forgotten and ultimately abandoned. Racialisation centres on the anti-conservative-Muslim, which is seen as a problem for multiculturalism as well as a security concern. Originally, Birmingham local authority was keen to dispel fears over Islamism in Birmingham when the matter entered into the public domain. This was largely because they wanted to project the reputation of the city, which continues to come to terms with deindustrialisation whilst it grows ever more ethnically, religiously and culturally diverse. Education managers in Birmingham City Council have been complicit in overlooking the realities facing young Muslims in education. There is racism at the heart of this problem because, in many senses, the city of Birmingham has been a "laboratory" for race and ethnic relations since the 1960s. Given its growing diversity and its changing post-industrial landscape, there is every likelihood that it will remain an important site for city-level understandings of post-war race, ethnicity and multiculturalism in Britain ( Wilson 2015).

Michael Gove, briefly Lord Chancellor and Secretary of State for Justice when the Conservatives formed a majority government in June 2015, now sits on the backbenches after his failed Conservative Party leadership bid. A contest arose when David Cameron stepped down as PM after his policies led to the Brexit vote in June 2016. The idea of values — not in the cultural sense, but in the political, has firmly entered into the realm of public policy. The "Trojan Horse" saga sanctioned a vast array of counter-terrorism legislation-including protecting "British values". The presumption that promoting "British values" will eliminate structural inequalities that appear because of modern racism in society inherent since the days of empire and colonialism is nonsensical, dismissive and patronising. It merely reproduces the status quo, and recreates the conditions for disadvantage and discrimination.

It is an attempt to hold on to the preserve of Britishness in the face of its ongoing disintegration (Tomlinson 2015). It is retreat into an imagined unitary whole, based on notions of its greatness, once lauded across the world, helping to cement an ever narrowing definition of insider and outsider, included and excluded. In all cases, it reaffirms racism. The "Trojan Horse" tale was a realisation of the extent of this racism, now wholly concentrated on Muslims in Britain through the governmentality of counter-extremism policy frameworks Gearson and Rosemont 
2015). Projected as representing all that is least desired about the self, the irony is that British Muslims, in reality, are more a part of British life than ever.

\section{CONCLUSION}

In an ironic twist, education is arguably the primary solution to radicalization (Siekelink, Kaulingfreks and De Winter 2015). The administration, management and leadership behind these "Trojan Horse" schools placed considerable emphasis on empowering young Muslims to know their religious character. It equipped pupils to appreciate the depth and nuances of Islam, bestowing young people with the courage and wisdom to counter the narratives propounded by the likes of Islamic State. The latter exposes the lack of Islamic awareness among disaffected youth subsequently exploited by those who seek to replace the vacuum with a sense of belonging, knowing and self-actualisation thus far denied. In the context of deep racism, discrimination, inequality and marginalisation facing many British Muslim groups in the inner cities today, an inspired programme of self-awareness in education coupled with academic scholarship is a solution that plainly functions in a climate that seeks to present all the problems of society as the problems of Muslims. The "Trojan Horse" affair merely uncovered the fear and loathing of conservative Islam and pious

Muslims in sectors of society who have the most power but the least understanding or gumption about the causes of radicalisation beyond the rhetoric that the source is conservative Islam or a lack of "values". "The answer to extremism is not moderation, but a highly critical and informed idealism" (Davies 2015).

The dominant paradigm is to continue to accept underperformance among these young Muslims as an unbreakable chain. In the mid-1980s, the Birmingham education system severely damaged the life chances of young people in inner city areas when school closures concentrated deprivation and disadvantage. The 1990s highlighted mismanagement and poor leadership in these same schools. The current generation of young Muslims in inner city Birmingham are in the exact identical schools and in precisely the same areas. Over the past four decades, little seems to have changed. In this time, the education system has failed tens of thousands of young Muslim children in schools in the inner cities of Birmingham.

Beyond the realm of education, there is also the wider problem of misrecognising the city of Birmingham as a "hotbed" of radicalisation and violent extremism, an issue that very much came to the fore in the light of the Westminster attacks on 22 March 2017. As the assailant had lived in the city for a period, albeit a matter of a few months, it was enough to create a global outcry in relation to questions of radicalisation and the identity of an entire city. 


\section{ACKNOWLEDGEMENTS}

This was an independently funded research project and originally published in the Journal of Muslim Minority Affairs, 2017 Vol. 37, No. 4, 426-441. It is reproduced by kind permission of the author.

\section{REFERENCES}

Abbas, T., (2004) "Teacher Perceptions of South Asians in Birmingham Schools and Colleges", Oxford Review of Education, Vol. 28, No. 4, 2002, pp. 447-471; Tahir Abbas, "Structural and Cultural Racism in the Educational Underachievement of British South Asian Muslims", in South Asians in Diaspora: Histories and Religious Traditions, eds. K Jacobson and P Kumar, Leiden: Brill, 2004, pp. 269-293.

Abbas, T., (2010) "Muslim on Muslim Social Research: Knowledge, Power and Religio-Cultural Identities", Social Epistemology: A Journal of Knowledge, Culture and Policy, Vol. 24, No. 2, 2010, pp. 123- 136.

Adamson, F. (2011) "Engaging or Contesting the Liberal State? 'Muslim' as a Politicised Identity Category in Europe", Journal of Ethnic and Migration Studies, Vol. 37, No. 6, 2011, pp. 899-915.

Ahmad, W and Sardar, Z (2012), Muslims in Britain: Making Social and Political Space, eds. Abingdon: Routledge.

Allen, C ( 2010), Islamophobia, Abingdon: Routledge, 2010; Salman Sayyid and Abdoolkarim Vakil, Thinking Through Islamophobia, eds. London: Hurst and New York: Columbia University Press,

Awan, I. (2014) “Operation 'Trojan Horse': Islamophobia or Extremism?", Political Insight, Vol. 5, No. 22, 2014, pp. 38-39.

Bhatti, G. (2004) "Outsiders or Insiders? Identity, Educational Success and Muslim Young Men in England', Ethnography and Education, Vo1. 6, No. 1, pp. 81-96.

Birmingham Mail, (2014) http://www.birminghammail.co.uk/news/midlandsnews/trojan-horse-jihadist-plot-take-6782881, 9 June 2014.

Clarke, P (2014) Report into Allegations Concerning Birmingham Schools Arising from the 'Trojan Horse' Letter, London: Crown,

Cowden, S. and Singh., G (2014), "Social Cohesion in the New Age of Capital: From Moral Imperative to Moral Panic", in Workshop Proceedings: Sense of Belonging in a Diverse Britain, London: Dialogue Society, 2014, pp. 27-40, p. 33

Daun, H. and Walford, G. eds (2004) . Educational Strategies Among Muslims in the Context of Globalization: Some National Case Studies. Leiden: Brill, 2004. 
Davies, L., (2016) "Security, Extremism and Education: Safeguarding or Surveillance?", British Journal of Educational Studies,

Gearson, J. and Rosemont, H. (2015) "CONTEST as Strategy: Reassessing Britain's Counterterrorism Approach", Studies in Conflict \& Terrorism, Vol. 38, No. 12, 2015, pp. 1038-1064; Katy Pal Sian, "Spies, Surveillance and Stakeouts: Monitoring Muslim Moves in British State Schools", Race Ethnicity and Education, Vol. 18, No. 2, 2015, pp. 183-201.

Gilligan, A. (2014) http://www.telegraph.co.uk/education/educationnews/10899804/ Trojan-Horse-how-we-revealed-the-truth-behind-the-plot.html, 15 June 2014; Andrew Gilligan, http://www. telegraph.co.uk/education/10978302/Trojan-Horseplot-teachers-keep-jobs.html, 20 July 2014; Andrew Gilligan, http://www. telegraph.co.uk/education/educationnews/10983691/Trojan-Horse-apologistsfall-silent-in-wake-of-new-report.html, 22 July 2014; Andrew Gilligan, http:// www.telegraph.co.uk/education/educationnews/11157116/Trojan-Horse-just-the-tipof-the-iceberg.html, 12 October 2014; Andrew Gilligan, http://www.telegraph. co.uk/education/educationnews/11171547/Revealed-the-private-academy-set-upby-teachers-barred-over-Trojan-Horse-plot.html, 18 October 2014; Andrew Gilligan, http://www.telegraph.co.uk/news/uknews/law-and-order/11381925/ Another-Birmingham-school-put-in-special-measures-amid-Trojan-Horse-fears. html, 31 January 2015; Andrew Gilligan, http://www.telegraph.co.uk/news/ religion/11413815/Police-chief-investigated-over-Trojan-horse-school-leak.html, 15 February 2015; Andrew Gilligan, http://www.telegraph.co. uk/education/ educationnews/11673313/Schools-watchdog-with-links-to-extremistsshut-down.html, 14 June 2015; Andrew Gilligan,http://www.telegraph.co.uk/ education/educationnews/11763319/Banned-staff-revealed-to-be-teaching-atTrojan-horse-school.html, 26 July 2015.

Halsey, A. , Heath, A., and Ridge, J. (1980), Origins and Destinations: Family, Class and Education in Modern Britain, Oxford: Oxford University Press.

Hasan, M. (2014), When Did Michael Gove Become the Government's Expert on Muslims or Extremism? http://www.huffingtonpost.co.uk/2014/06/04/michaelgove-islam_n_5443576.html, 4 June 2014.

Hoque, A. (2015) British-Islamic Identity: Third-Generation Bangladeshis from East London, Stoke-on-Trent: Trentham Books

James, A. (2015) "Extremism and Neo-Liberal Education Policy: A Contextual Critique of the Trojan Horse Affair in Birmingham Schools", British Journal of Educational Studies, Vol. 63, No. 3, 2015, pp. 311-328, p. 319.

Kashya, R. and Lewis, V. (2013) "British Muslim Youth and Religious Fundamentalism: A Quantitative Investigation', Ethnic and Racial Studies, Vol. 36, No. 12, 2013, pp. 2117-2140.

Kershaw, I. (2014 Investigation Report: Trojan Horse Letter, Birmingham, Birmingham City Council 
Kundnani, A. (2014) The Muslims Are Coming! Islamophobia, Extremism, and the Domestic War on Terror, London: Verso.

Meer, N. (2013) "Identity Articulations, Mobilization, and Autonomy in the Movement for Muslim Schools in Britain', Race Ethnicity and Education, Vol. 12, No. 3, 2009, pp. 379-399; Joyce Miller, "Resilience, Violent Extremism and Religious Education", British Journal of Religious Education, Vol. 35, No. 2, 2013, pp. $188-200$.

Miah, S. (2015) Muslims Schooling and the Question of Self-Segregation, Basingstoke: Palgrave Macmillan.

Mogra, I., (2015) "The 'Trojan Horse' Affair and Radicalisation: An Analysis of Ofsted Reports", Edu cational Review, 2015 iFirst,

Morris, S., and Wintour, P., (2014) http://www.theguardian.com/education/2014/ jun/09/trojan-horse-row-birmingham-schools-special-measures-ofsted, 9 June 2014.

Mythen, G., Walklate, S. and Khan, F. (2009) "I'm a Muslim, but I'm not a Terrorist': Victimization, Risky Identities and the Performance of Safety", British Journal of Criminology, Vol. 49, No. 6, , pp. 736-754.

O'Donnell, A. (2015) "Securitisation, Counterterrorism and the Silencing of Dissent: The Educational Implications of Prevent", British Journal of Educational Studies, DOI: 10.1080/00071005.2015.1121201, iFirst, 2015.

Parker-Jenkins, M. (2002 "Equal Access to State Funding: The Case of Muslim School", Race, Ethnicity and, Education, Vol. 5, No. 3, pp. 273-289.

Pidd, H. and Dodd, V. (2014) http://www.theguardian.com/uk-news/2014/apr/15/ police-chief-counter-terror-officer-islamic-schools-plot-birmingham,

Richardson, R., (2015) "Narrative, Nation and Classrooms: The Latest Twists and Turns in a Perennial Debate", in The Runnymede School Report: Race, Education and Inequality in Contemporary Britain, eds. Claire Alexander, Debbie Weekes-Bernard and Jason Arday, London: Runnymede Trust, pp. $14-16$, p. 15.

Richardson, R. (2015), "British Values and British Identity: Muddles, Mixtures, and Ways Ahead", London Review of Education, Vol. 13, No. 2, pp. 37-48.

Salih, R. (2004)"The Backward and the New: National, Transnational and PostNational Islam in Europe", Journal of Ethnic and Migration Studies, Vol. 30, No. 5, 2004, pp. 995-1011.

Shah, S. (2006) "Educational Leadership: An Islamic Perspective", British Educational Research Journal, Vol. 32, No. 3, pp. 363-385.

Shah, S. and Shaikh, J. (2010) "Leadership Progression of Muslim Male Teachers: Interplay of Ethnicity, Faith and Visibility', School Leadership and Management: Formerly School Organisation, Vol. 30, No. 1, 2010, pp. 19-33.

Shah, S (2015), Education, Leadership and Islam: Theories, Discourses and Practices from an Islamic Perspective, Abingdon: Routledge. 
Shain, F. ( 2013) "Race, Nation and Education: An Overview of British Attempts to 'Manage Diversity' Since the 1950s", Education Inquiry, Vol. 4, No. 1, 2013, pp. 63-85.

Sieckelinck, S. Kaulingfreks, F. and De Winter, M. (2015) "Neither Villains Nor Victims: Towards an Educational Perspective on Radicalisation", British Journal of Educational Studies, Vol. 63, No. 3, 2015, pp. 329-343.

Smith, D. and Tomlinson, S., (1989) The School Effect: A Study of Multi-Racial Comprehensives, London: PSI.

Tinker, C and Smart, A., (2012) "Constructions of Collective Muslim Identity by Advocates of Muslim Schools in Britain", Ethnic and Racial Studies, Vol. 35, No. 4, 2012, pp. 643-663.

Tomlinson, S., (2008) Race and Education: Policy and Politics in Britain, Berkshire: Open University Press/McGraw-Hill Education, p. 233.

Tomlinson, S. (2015) "The Empire Disintegrates", Ethnic and Racial Studies, Vol. 38, No. 13, 2015, pp. 2208-2215.

Wilson, H. (2015) "An Urban Laboratory for The Multicultural Nation?", Ethnicities, Vol. 15, No. 4, 2015, pp. 586-604. 